\section{Review of Evidence for Alcohol-Based Skin Preparation Agents}

To the Editor-We report that surgical site infections (SSIs) remain a major problem despite nearly a decade of national efforts to implement various practice-based recommendations targeting SSIs. According to a 2012 US Department of Health and Human Services news release, "Every day, approximately 1 in every 20 patients has an infection related

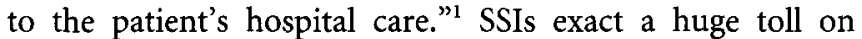
patients and remain a leading cause of preventable deaths. SSIs are also responsible for escalating healthcare-associated financial costs.

Two well-known recommended practices aimed at reducing SSIs are the administration of prophylactic antibiotics prior to surgery and the use of skin preparation agents. The prophylactic antibiotic practices recommended as part of the Centers for Medicare and Medicaid Services Surgical Care Improvement Program have been widely recommended and implemented. Multiple studies have shown that the timing of the initial dose of prophylactic antibiotics, appropriate choice of prophylactic antibiotic, and maintaining adequate serum levels of antibiotics throughout the procedure impact SSIs. ${ }^{2}$ However, the impact of prophylactic antibiotic practices is questionable because SSI rates have not shown a significant decline, ${ }^{3}$ suggesting that other preventive practices, such as use of skin preparation agents with or without alcohol embedded in them, need to be investigated further.

The most commonly used skin preparation agents are io- dine (eg, povidone-iodine) and chlorhexidine gluconate (chlorhexidine or CHG). Both are available with or without alcohol embedded in the skin preparation. Alcohol is readily available, inexpensive, and remains the most effective and rapid-acting skin antiseptic. Most antiseptic solutions used for degerming skin contain 1 or a combination of the active ingredients: alcohol, chlorhexidine gluconate, or iodine. Both chlorhexidine and iodophors address broad spectra of antimicrobial activity. Chlorhexidine is not inactivated by blood or serum proteins. However, iodophors may be inactivated by blood or serum proteins but exert a bacteriostatic effect as long as they are present on the skin. Alcohol's principal antimicrobial activity is achieved by denaturing bacterial proteins. Concentrations of alcohol above $60 \%$ are most effective. Both gram-negative and gram-positive bacteria are highly susceptible to alcohol. Alcohol does provide a quick germicidal kill but lacks any sustained activity. ${ }^{4}$

Table 1 provides an overview of studies that have investigated the effectiveness of various skin preparation agents. A comparison of studies evaluating skin preparation agents shows a predominance of general surgery-related procedures, however, which limits direct comparisons for specific procedures. The National Quality Forum (NQF) practice recommendations for alcohol-based skin preparation agents are primarily derived from 2 studies. ${ }^{5}$ First, Swenson et al ${ }^{6}$ reported significantly lower infection rates for the iodine alcohol preparation than for chlorhexidine with alcohol or a non-alcohol-based skin preparation agent, using a sequential time-based evaluation. Subsequently, Darouiche et $\mathrm{al}^{7}$ compared 1 alcohol-based (chlorhexidine) and 1 non-alcohol-

TABLE 1. Summary Findings for Comparison of Skin Preparation Agents

\begin{tabular}{|c|c|c|c|}
\hline Study & Comparison & Study design & Findings \\
\hline Swenson et $\mathrm{al}^{6}$ & $\begin{array}{l}\text { Povidine-iodine scrub-paint vs } 2 \% \\
\text { CHG and } 70 \% \text { alcohol vs iodine } \\
\text { povacrylex in isopropyl alcohol } \\
\text { (NSQIP; general, vascular surgery) }\end{array}$ & $\begin{array}{l}3 \text { products, sequential in } \\
\text { time-based evaluation } \\
(n=3,209)\end{array}$ & $\begin{array}{l}\text { Iodine povacrylex in isopropyl alcohol } \\
\text { has lowest SSI rate }(P=.002)\end{array}$ \\
\hline Darouiche et $\mathrm{al}^{7}$ & $\begin{array}{l}2 \% \text { chlorhexidine and } 70 \% \text { alcohol vs } \\
\text { povidine-iodine (clean contami- } \\
\text { nated, colorectal, small intestinal, } \\
\text { gastroesophageal, biliary, thoracic, } \\
\text { gynecologic, or urologic operations } \\
\text { without substantial spillage or } \\
\text { contamination) }\end{array}$ & $\begin{array}{l}\text { Randomly assigned ( } n= \\
\text { 849), multihospital } \\
\text { study }\end{array}$ & $\begin{array}{l}2 \% \text { chlorhexidine and } 70 \% \text { alcohol } \\
\text { skin preperation had significantly } \\
\text { lower SSI rate }(P=.004) \text { than } \\
\text { povidine-iodine (no alcohol) }\end{array}$ \\
\hline Paocharoen et $\mathrm{al}^{10}$ & $\begin{array}{l}\text { Povidone-iodine vs } 4 \% \text { chlorhexidine } \\
\text { and } 70 \% \text { alcohol (clean contami- } \\
\text { nated, general surgery) }\end{array}$ & $\begin{array}{l}\text { Prospective randomized } \\
\quad \text { trial }(n=500)\end{array}$ & $\begin{array}{l}4 \% \text { chlorhexidine and } 70 \% \text { alcohol } \\
\text { had significantly lower SSI rate }(P< \\
.05)\end{array}$ \\
\hline Berry et al ${ }^{11}$ & $\begin{array}{l}\text { Alcoholic povidone-iodine vs alcoholic } \\
\text { chlorhexidine (biliary tract, large } \\
\text { bowel, laparotomy, hernia, genitalia, } \\
\text { varicose veins, clean nonabdominal) }\end{array}$ & $\begin{array}{l}\text { Random assignment }(n= \\
\quad 866)\end{array}$ & No significant difference in SSIs \\
\hline
\end{tabular}

Note. CHG, chlorhexidine gluconate; NSQIP, National Surgical Quality Improvement Program; SSI, surgical site infection. 
based (povidine-iodine) skin preparation agent and established a significantly lower infection rate for the alcohol-based product as well. Although Darouiche et $\mathrm{al}^{7}$ used a randomly assigned, multihospital design, the study population included a large number of procedures grouped together, and the comparison involved 1 agent (iodine) without alcohol and 1 agent (chlorhexidine) with alcohol, thus lacking a comparison of the same agent base-ingredients (iodine vs chlorhexine). Efforts were made to include a random or prospective component in the study design, but most studies have been limited to single-site hospitals. Only 1 study, Swenson et al, ${ }^{6}$ compared both iodine- and chlorhexidine-based skin preparation agents with alcohol and reported lower surgical site infection rates for the povidone-iodine with alcohol group. Studies that compared any alcohol-based product demonstrated lower SSI rates than those without an alcohol-based product, in support of the NQF's recommendation. A major limitation of these studies is the absence of information about prophylactic antibiotic use and the potential variation in the measurement of surgical site infections. Lee et $\mathrm{al}^{8}$ conducted a meta-analysis of 9 studies and determined a significantly lower risk-adjusted SSI rate when chlorhexidine was used. Noorani et $\mathrm{al}^{9}$ based his meta-analysis on 6 studies and also established that chlorhexidine was associated with a lower rate of SSIs. Neither meta-analysis distinguished between studies that compare skin preparation products with and without alcohol; the included studies used multiple procedure groups as well as varying SSI definitions.

In sum, current evidence favors the use of chlorhexidine; however, the specific contribution of alcohol embedded in either povidone-iodine or chlorhexidine is unclear. The current level of evidence supporting this NQF recommendation lacks multiple randomized clinical trials. Future studies should conduct a prospective randomized comparison of chlorhexidine- and iodine-based products, both with and without alcohol, applied to specific patient procedures. Adjustment for and evaluation of prophylactic antibiotics is recommended to evaluate the specific effects of alcohol-based skin preparation agents given the presence of prophylactic antibiotics while also controlling for patient and contextual factors. In addition, evaluation of proper adherence to skin preparation application guidelines is necessary to ascertain a potential impact on outcomes. Adherence to recommended national practices for skin preparation may be improved with clear evidence indicating the specific contributions of a particular skin preparation agent in combination with prophylactic antibiotics for defined procedures and patient populations.

\section{ACKNOWLEDGMENTS}

Potential conflicts of interest. All authors report no conflicts of interest relevant to this article. All authors submitted the ICMJE Form for Disclosure of Potential Conflicts of Interest, and the conflicts that the editors consider relevant to this article are disclosed here.

\section{AkkeNeel Talsma, PhD, RN, FAAN; ${ }^{1}$}

Carol E. Chenoweth, $\mathrm{MD}^{2}$

Affiliations: 1. School of Nursing, University of Michigan, Ann Arbor, Michigan; 2. University of Michigan Health System, Infectious Diseases, Ann Arbor, Michigan.

Address correspondence to AkkeNeel Talsma, PhD, RN, FAAN, School of Nursing, University of Michigan, 400 North Ingalls, Room 4154, Ann Arbor, MI 48109 (antalsma@umich.edu).

Infect Control Hosp Epidemiol 2012;33(10):1059-1060

(C) 2012 by The Society for Healthcare Epidemiology of America. All rights reserved. 0899-823X/2012/3310-0018\$15.00. DOI: $10.1086 / 667737$

\section{REFERENCES}

1. HHS seeks comment on National Action Plan to eliminate healthcare-associated infections. US Department of Health and Human Services website. http://www.hhs.gov/news/press /2012pres/04/20120419a.html. Published 2012. Accessed April 2012.

2. Bratzler DW, Houck PM. Antimicrobial prophylaxis for surgery: an advisory statement from the National Surgical Infection Prevention Project. Clin Infect Dis 2004;38:1706-1715.

3. Nicholas LH, Osborne NH, Birkmeyer JD, Dimick JB. Hospital process compliance and surgical outcomes in Medicare beneficiaries. Arch Surg 2010;145(10):999-1004.

4. Garcia R. Surgical skin antisepsis. Periop Nurs Clin 2010;5: 457-477.

5. NQF maintains endorsement of safe practice to prevent surgical site infection. National Quality Forum website. www .qualityforum.org/News_And_Resources/Press_Releases/2011 /NQF_Maintains_Endorsement_of_Safe_Practice_to_Prevent _Surgical_Site_Infection.aspx. Published 2011. Accessed April 2012.

6. Swenson BR, Hendrick TL, Metzger R, Bonatti H, Pruett TL, Sawyer RG. Effects of preoperative skin preparation on postoperative wound infection rates: a prospective study of 3 skin preparation protocols. Infect Control Hosp Epidemiol 2009; 30(10):964-971.

7. Darouiche RO, Wall MJ, Itani K, et al. Chlorhexidine-alcohol versus povidone-iodine for surgical-site antisepsis. $N$ Engl J Med 2010;362(1):18-26.

8. Lee I, Agarwal RK, Lee BY, Fishman NO, Umscheid CA. Systematic review and cost analysis comparing use of chlorhexidine with use of iodine for preoperative skin antisepsis to prevent surgical site infection. Infect Control Hosp Epidemiol 2010;31(12): 1219-1229.

9. Noorani A, Rabey N, Walsh SR, Davies RJ. Systematic review and meta-analysis of preoperative antisepsis with chlorhexidine versus povidine-iodine in clean-contaminated surgery. Br J Surg 2010;97:1614-1620.

10. Paocharoen V, Mingmalairak C, Apisarnthanarak A. Comparison of surgical wound infection after preoperative skin preparation with $4 \%$ chlorhexidine and povidone iodine: a prospective randomized trial. J Med Assoc Thailand 2009;92(7):898-902.

11. Berry AR, Wabb B, Goldacre MJ. A comparison of the use of povidone-iodine and chlorhexidine in the prophylaxis of postoperative wound infection. J Hosp Infect 1982;3(1):55-63. 